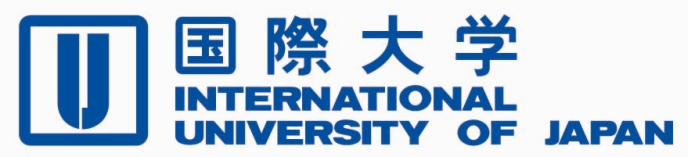

Economics \& Management Series

EMS-2012-16

\title{
Environmental Shocks, Collaborative Networking, and Organizational Performance:Evidence from Hurricane Rita
}

\author{
Sangyub Ryu \\ International University of Japan
}

September 2012

IUJ Research Institute

International University of Japan

These working papers are preliminary research documents published by the IUJ research institute. To facilitate prompt distribution, they have not been formally reviewed and edited. They are circulated in order to stimulate discussion and critical comment and may be revised. The views and interpretations expressed in these papers are those of the author(s). It is expected that the working papers will be published in some other form. 
Environmental Shocks, Collaborative Networking, and Organizational Performance:

Evidence from Hurricane Rita

Sangyub Ryu

Public Management and Policy Analysis Program

Graduate School of International Relations

The International University of Japan

777 Kokusai-cho, Minami Uonuma-shi

Niigata, 949-7277, Japan

Email: sangyubr@iuj.ac.jp 


\begin{abstract}
The literature has found that there is a link between an organization's environment and its performance. Some organizational theorists argue that management plays only a marginal role in this link. The present study objects to this argument. The literature on public management has observed that stability in an administrative system and collaborative networking with external actors can manage environmental influences. In an emergency context, public management literature has given more emphasis on collaborative networking than stability due to the need for timely application. Focusing on the role of collaborative networking in the environmentperformance link in an emergency context, this study examined the negative influences of Hurricane Rita on organizational performance. Furthermore, this study investigated how collaborative networking with emergency-relevant actors moderates the negative relationship. From Texas school district data, it was found that days of school closure due to Hurricane Rita (environmental shocks) lowered the overall students' academic achievement (organizational performance), but superintendents' regular meetings with external actors in preparation for emergencies (collaborative networking) moderated the decrease in students' academic performance. The findings of this study support the proposition that management matters to organizational performance.
\end{abstract}

Keywords: collaborative networking; public management; emergency management; organizational performance 


\section{INTRODUCTION}

Organizational performance is determined by various factors; some are controllable and others are not. Some contend that management cannot significantly influence organizational performance when uncontrollable factors such as natural disaster are considered. That is, environmental factors explain the variation of organizational performance so much that management can explain only a little variation in performance. This study objects to this argument. Management may not be able to keep uncontrollable factors including environmental shocks from happening, but it is a core aspect of management to moderate the negative effects of uncontrollable factors on organizations and their performance (Meier and O’Toole 2009a).

Earlier, O’Toole and Meier (1999) proposed a contingent model to predict organizational performance. According to their model, organizational performance is partly influenced by environmental factors, but they argue that stability in an administrative system and managerial efforts to network with their environmental actors can manage the environment-performance link. In most cases, organizations are affected by their environment and it is almost impossible to break the environment-performance link. However, if the O'Toole-Meier model holds, management can develop strategies to control this link: if the link is negative, management can minimize the negativity; if the link is positive, management can maximize the positivity.

The focus of this study is on the negative link between the environment and

organizational performance with special attention to management's moderating role. Using evidence from Hurricane Rita in 2005, this study investigates how environmental shocks negatively influenced organizational performance and how collaborative networking moderated the negative link. 


\section{PUBLIC MANAGEMENT AND ORGANIZATIONAL PERFORMANCE}

Some organization theories, including population-ecology theory, emphasize the effects of the environment surrounding the organization. They argue that the success or failure of an organization is not determined by management itself (or what managers do) but by other external events which managers cannot control (Rainey, 2009). In addition, they contend that public management is so constrained or controlled by its political environment that public managers have very little discretion to influence organizational or program performance through their management (Rainey, 2009). In this regard, Kaufman $(1981,135)$ described the extent of public manager's influence as "in inches, not miles."

However, researchers have proposed and tested a number of ways in which managers influence outputs and outcomes of organizational or program performance (Meier and O'Toole, 2009b). Classical organizational theorists focused on organizational structures to influence organizational performance. For instance, Taylor (1911) emphasized scientific management to improve organizational efficiency and Gulick (1937) proposed POSDCORB $^{1}$ as an effective manager's role to improve organizational performance. Gulick's principles of management are still valid in modern organization theory (Meier and Bohte, 2000). Empirical studies have supported the significance of organizational structure for better performance. Some examples include the association between organizational performance and structure of decision-making authorities (Andrew 2010; Andrew et al. 2009), rules and red-tape (Bozeman 2000; Brewer and Walker 2010; Pandey, Coursey, and Moynihan 2007), or communication (Child and Rodrigues 2003).

\footnotetext{
${ }^{1}$ POSDCORB refers to planning, organizing, staffing, directing, coordinating, reporting, and budgeting.
} 
Other theorists, on the other hand, focused on human behavior and motivation in improving organizational performance (Maslow 1943; Mayo 1949; McGregor 1960). Research in this area has found that managing people also significantly influences organizational performance. Some of these studies emphasized leadership styles (for instance, Behn 1994; Trottier, Van Wart, and Wang 2008) and/or employee motivation (for instance, Park and Rainey 2008; Wright 2004).

Meanwhile, the study of public management has gradually shifted its focus of management from a single organization to a setting of multiple organizations, collaborative networks. Collaborative networks are a set of governmental and non-governmental actors in order to achieve a public goods, services, or values with which a single governmental organization cannot provide fully and with which nongovernmental organizations are unable or unwilling to provide in the desired quantities (Rethemeyer and Hatmaker, 2008). This shift resulted from the occurrence of complex public problems or goals, which a single public organization is unable to fully resolve or achieve (Agranoff and McGuire 2003; Rittel and Webber 1973). According to Berry and her colleagues (2004), public management studies on networks have taken two different levels of analysis (network level of network structures and individual level of networking behaviors) and empirical research found significant effects of network structures and networking behaviors on organizational and/or program performance (see, O’Toole and Meier 2001; Provan and Milward 1995).

In summary, the development of research on network structure and networking behavior as well as organizations and the people within them suggests that management matters to organizational performance and that managers are expected to take actions to improve organizational performance (Moynihan and Pandey, 2005). 


\section{PUBLIC MANAGEMENT AND BUFFERING ENVIRONMENTAL SHOCK}

If organizations lie in stable environments, managers may be able to improve organizational performance by putting most efforts to the internal management of organizations. However, almost all organizations operate in an uncertain environment that affects them one way or another, and it implies that successful management styles and organizational structures are determined depending on the characteristics of the environment. As a result, understanding and managing the environment is as important as managing organizations (Boyne and Meier 2009; O’Toole and Meier 1999; Meier, O’Toole and Hicklin 2010; Waugh and Streib 2006).

The influence of an organization's environment includes any type of disruption emanating from outside the administrative system that threatens the core of the organization (Meier and O'Toole, 2009b, 487). Environmental shocks may be positive and beneficial to the organization's performance: good economic conditions, abundant external resources, or favorable statutes. Managers may want to exploit these opportunities through various management strategies.

The focus of this study is more on negative environmental shocks that threaten the core missions of the organization. In such cases, managers are prone to take defensive, protective actions to buffer negative shocks and stabilize their organizations (Meier and O'Toole, 2009a, 2009b). In this regard, O’Toole and Meier (2003, 2011) emphasized developing organizational stability such as personnel stability, procedural stability, production/technology stability, mission stability, and structural stability. In doing so, public management can limit uncertainties and protect organizational core functions (Boyne and Meier 2009; Meier, O’Toole, and Hicklin 2010; Thompson 1967). 
In addition to stability, networking with relevant external actors has also been seen as a means of buffering environmental shocks (Meier and O'Toole, 2003; Nicholson-Crotty and O’Toole, 2004; O'Toole and Meier, 1999, 2011). According to resource dependence theory, individual organizations do not have all the resources they need to accomplish their goals, and they attempt to fulfill their shortcomings by depending on resources from external actors (Fleishman, 2009). Individual organizations are almost unable to possess the resources necessary to handle their environment and buffer shocks. Thus, managers network with external actors who can provide needed resources and expertise. As a result, managers' networking activities become significant management strategies. Empirical findings support the role of networking as a means of buffering negative environmental shocks. For instance, O'Toole and Meier (2011) partially confirmed that superintendents' active networking with their local partners mitigates negative impacts of instructional task difficulties on students' academic achievement in Texas school districts. Similarly, with U.S. law enforcement cases, Nicholson-Crotty and O’Toole (2004) found that chief officers' networking activities moderated the negative association between high crime rates and clearance rates in local communities.

If networking strategies operate to protect core functions of an organization from an environment, the discussion can be extended to an emergency context since emergencies are massive environmental shocks.

\section{COLLABORATIVE NETWORKING IN AN EMERGENCY CONTEXT}

Emergencies such as natural disasters are evident environmental shocks that negatively influence organizations and their performance. Thus, if management matters to organizational performance, it should be able to buffer or, at least, moderate environment's negative effects on an organization's performance. Emergency management studies emphasize stability in an 
administrative system (procedural stabilities), such as emergency plans, or a mode of communication and a hierarchy of authority (structural stabilities). However, some scholars of emergency management focus more on collaborative networking by pointing out the limitation of administrative stability in a real emergency situation (Comfort 1999; Kapucu 2008; Kapucu, Arslan, and Demiroz 2010; Kapucu, Augustin, and Garayev 2009; McGuire and Silvia 2010; Waugh and Streib 2006). For instance, Waugh and Streib (2006) contend that stability may not be as effective as it ought to be because an emergency occurs in uncertain circumstances in which plans do not fit. Rather, they stress collaborative networks as "a fundamental component of any emergency response" (132). There are a few incentives to use networking as an emergency management strategy. First, few single organizations can manage massive environmental shocks such as natural disasters. Fire departments used to be the main organization to manage such situations (Erickson 1999) but as Hurricane Katrina showed, multiple organizations are needed to manage a disaster. Second, although environmental shocks should be managed to improve organizational performance, an organization should not spend most of its resources on managing these shocks especially when these are random and of considerable magnitude. Rather, it is a better strategy to share risks with other organizations by networking. Furthermore, networking enables organizations to realize economies of scale so that they may be able to manage their environment with less cost and effort while achieving desired outcomes.

Based on the literature reviewed so far, this study tests the following hypotheses:

H1: Negative environmental shocks directly lower organizational performance

H2: Networking with relevant external actors moderates the negative link between environmental shocks and organizational performance. 
To test hypotheses, this study adopts the O'Toole-Meier model (O'Toole and Meier, 1999), and modifies it to apply to the case of Hurricane Rita.

\section{THE MODEL}

This study adopts O'Toole and Meier's (1999) contingent model to understand how networking moderates the negative effects of an emergency on organizational performance. The original model is as follows:

$$
O_{t}=\beta_{1}\left(S+M_{1}\right) O_{t-1}+\beta_{2}\left(X_{t} / S\right)\left(M_{2}\right)+\varepsilon_{t}
$$

where

$O$ denotes some measures of organizational performance,

$S$ is some measure of stability including structural, procedural, or other factors that support consistent production,

$M_{1}$ is managerial effort to stabilize the organization through addition to hierarchy/structure as well as regular operations,

$M_{2}$ is managerial effort to buffer the environmental shocks and/or exploit resources from the environments, some portion of which may be collaborative,

$X$ is an environmental shock which can be divided into resources and constraints associated with the environment, $\varepsilon$ is an error term, the subscripts of $t$ and $t-1$ denotes time periods, and $\beta_{1}$ and $\beta_{2}$ are estimable parameters (O’Toole and Meier, 1999; Meier, O’'Toole, and Hicklin, 2010). 
O'Toole and Meier (1999) argue that current organizational performance is mostly influenced by past organizational performance because of inertial characteristics and environmental factors. They suggest that organizational stability and managerial efforts can moderate the impact of an organization's past performance. Also, they contend that organizational stability and external management including managerial networking can buffer the negative environmental shocks as well as exploit opportunities from the environment. The focus of this study is on the moderating role of networking in the negative relationship between environmental shocks and organizational performance. Thus, this study modifies the O'TooleMeier model as follows:

$$
O_{t}=\beta_{1} O_{t-1}+\beta_{2} X_{h s}+\beta_{3} M_{2}+\beta_{4}\left(X_{h s} \times M_{2}\right)+\beta_{5} X_{t}+\varepsilon_{t}
$$

where

$O$ is some measure of organizational outcomes, $X_{h s}$ is the hurricane shock (days of school closure), $M_{2}$ is networking,

$X$ is a vector of environmental forces other than the hurricane shock, $\varepsilon$ is an error term, the subscripts $\mathrm{t}$ and $\mathrm{t}-1$ denote time period, and $\beta_{1}$ through $\beta_{5}$ are estimable parameters.

This modified model includes an interaction term of hurricane shocks and networking in order to test networking's moderating role. To test the negative impact of environmental shocks on organizational performance, this study will give special attention to the statistical significance and the direction of the beta coefficient corresponding to the hurricane shocks $\left(X_{h s}\right)$. Regarding networking's moderating role, this study will focus on the beta coefficient for the interaction 
term between the hurricane shocks and collaboration $\left(X_{h s} \times M_{2}\right)$. The following will detail the context of the study, a sample and variables.

\section{HURRICANE RITA AND SAMPLE}

This study uses the case of Hurricane Rita to investigate the role of management. Hurricane Rita, which was recorded as "the most intense tropical cyclone ever observed in the Gulf of Mexico," hit near the Texas and Louisiana border on September 24, 2005 (Meier, O’Toole, and Hicklin, 2010, 984). This event resulted in seven fatalities and $\$ 10$ billion in property damage. Figure 1 describes the path of the hurricane as well as the size and reach of its wind forces. The red, light green and light blue lines are the maximum reach of winds at more than 74 miles per hour (mph), more than $58 \mathrm{mph}$, and more than $39 \mathrm{mph}$, respectively. ${ }^{2}$

As described in Figure 1, Hurricane Rita did not affect most school districts in west Texas. This study tests how networking moderates the negative effects of Hurricane Rita on school districts' performance. Thus, districts unaffected by the hurricane may be an inappropriate sample for this analysis; thus, it is reasonable to set the boundary that distinguishes areas affected and unaffected by the hurricane and to drop unaffected districts out of the analysis.

First, all districts covered by winds 1) above $74 \mathrm{mph}$; 2) between $58 \mathrm{mph}$ and $74 \mathrm{mph}$; and 3) between $39 \mathrm{mph}$ and $58 \mathrm{mph}$ are included as a sample. To include school districts that were marginally affected by Hurricane Rita, this study draws a hypothetical line in a following way: first, the distance between the light blue line and the light green line is measured, and based

\footnotetext{
${ }^{2}$ According to the Beaufort Wind Scale, when the wind speed is faster than 73 miles per hour, the winds are categorized as hurricane force winds and it can cause extreme destruction/devastation and large waves over 14 meters. Tropical storm force winds have wind speeds of about 55 to 72 miles per hour, which can result in breaking or uprooting trees, extensive widespread damages, or large waves from 6 to 14 meters. Winds of 39 to 54 miles per hour are gales that can result in high waves (up to 6 meters) and slight damage to buildings. For more details please visit at http://www.marinewaypoints.com/marine/wind.shtml.
} 
on this distance, a hypothetical line apart from the light blue line is drawn. Districts in this area are affected by hurricane winds below $39 \mathrm{mph}$.

In summary, the sample for this study includes all school districts affected by the hurricane wind forces at (1) faster than $74 \mathrm{mph}$, (2) between 58 and $74 \mathrm{mph}$, (3) between 39-58 mph, and (4) less than $39 \mathrm{mph}$.

\section{DATA}

This study utilizes the post-hurricane survey entitled, "Emergency Preparedness and the Impact of Hurricanes Katrina and Rita on Texas School Districts." It was coordinated by researchers at Texas A\&M University and the University of Texas at Dallas. The collection of information from superintendents of Texas school districts was initiated right after Hurricanes Katrina and Rita (the initial survey was conducted in November, 2005 and finished by early 2006). The survey asked superintendents about the impact of the hurricanes on their school districts, such as the number of days that the district canceled classes or the number of evacuees from elsewhere who enrolled in their districts. The survey also asked for details of the pattern of collaboration in emergency response as well as the extent of emergency preparedness. 720 of the superintendents responded to the survey (response rate: 58 percent). Because the survey was conducted after the hurricanes, superintendents had to recall their management style. Therefore, their retrospective answers could be biased. By collecting survey data right after the hurricanes, the survey designer attempted to reduce such retrospective bias.

The survey also conducted a mean test of networking activities among school districts based on the severity of hurricane windforces. It was found that there were no statistically significant differences in networking activities among school districts regardless of the 
hurricane's impacts. The result implies that there was no endogeneity issue that the severity of the hurricane possibly influenced superintendents' networking activities.

In addition to the post-hurricane survey data, this study utilizes financial resources and demographic information related to the school districts from the Texas Education Agency website. $^{3}$

\section{Measuring organizational performance}

As the current organization's outcomes, this study uses a district's overall pass rates in the Texas Assessment of Knowledge and Skills (TAKS). The TAKS is a state-required, annual standardized test consisting of reading, writing, English language arts (ELA), mathematics, science, and social studies from grades 3 to 11 (Keng, McClarty, and Davis, 2008. 208). According to Meier and O'Toole (2003), the TAKS measures how much students achieve the basic academic skills as they move to upper grades. Although the pass rates of the TAKS may not entirely capture students' academic achievement, they do assess whether students obtain the basic academic knowledge from grade to grade. Moreover, the local community and school districts care about the TAKS results, thus, superintendents focus their management on improving the TAKS pass rates (Meier and O'Toole, 2003). This study is interested in districts' performance after Hurricane Rita, which hit in September 2005. Thus, the TAKS pass rates in 2006 is used as a dependent variable.

\section{Measuring environmental shocks}

The environmental shocks, or hurricane shocks, are operationalized by the number of days that classes were canceled due to Hurricane Rita. The logic is that canceled classes due to the delayed

\footnotetext{
${ }^{3}$ Academic Excellence Indicator System. 2011. Texas Education Agency. May 11, 2011.

$<$ http://ritter.tea.state.tx.us/perfreport/aeis/>
} 
school re-opening resulting from the hurricane may negatively affect students' learning and thus their TAKS pass rates.

The impact of canceled classes on students' test performance has to be carefully examined because only a few days of school closure may have caused a trivial impact on their performance. The Texas Education Agency (TEA) asked school districts to hold make-up classes if classes had been canceled more than 10 days due to Hurricane Rita (Texas Education Agency, 2005). In other words, the TEA treated the $10^{\text {th }}$ day as a threshold. According to Meier, O'Toole, and Hicklin (2010), 243 districts canceled their class for about 1 week (5.14 days), but only a few districts canceled their classes more than 2 weeks. As a result, they set the $6^{\text {th }}$ day as a threshold and examined the threshold effects on test performance. ${ }^{4}$ Because this study uses the same data set that Meier, O'Toole, and Hicklin used, their variable of days of school closure is first replicated. From the raw days of school closure, this study transforms days of school closure fewer than 6 into a value of zero. If the raw variable of days of school closure is equal to or greater than 6 , the transformed variable has the same value of the raw variable. For instance, the transformed variable has a value of 0 if days of school closure for a particular district were 3 and has a value of 8 if a particular district canceled classes for 8 days.

Although Meier, O’Toole and Hicklin (2010) find their measure of days of school closure negatively influence student performance, the current study raises one question: is the $6^{\text {th }}$ day an appropriate cut-off to estimate the negative influence of environmental shock on organizational performance? As Meier, O'Toole, and Hicklin argue, a few days of school closure may cause a trivial result but some level will lead to significant impacts. If their cut-off is appropriate, the TEA's recommendation of no make-up classes for districts that canceled fewer than 10 days

\footnotetext{
${ }^{4}$ Using this variable, Meier, O'Toole, and Hicklin find that canceled classes negatively influenced students' performance.
} 
could be an inappropriate decision. In order to check if the $6^{\text {th }}$ day is an appropriate cutoff, this study generates three dichotomous variables; 1) the first dichotomous variable has a value of one if there were no cancellation; 2) the second dichotomous variable has a value of one if days closed were between one day and five days; 3 ) and the third dichotomous variable has a value of one if days closed were 6 days or more. The strategy to determine the $6^{\text {th }}$ day as an appropriate cutoff is to find the third dichotomous variable representing school closure more than 6 days to be statistically significant and the second dichotomous variable denoting school closure between 1 day and 5 days statistically insignificant. Using the first dichotomous variable (no school closure) as a baseline, the current study puts an interaction term between the third dummy variable (school closure more than 5 days) and the networking variable.

\section{Measuring collaborative networking}

In this model, $M_{2}$ denotes superintendents' networking in response to the emergency. Although this study tests the impact of networking by following the O'Toole-Meier model, the way this study measures networking is different from how Meier and O'Toole $(2001,2005)$ measure networking. They investigate how much superintendents interact (on a six-point Likert scale from daily to never) with a few key environmental players, and conduct a factor analysis to capture managers' effort to manage the environment through networking. However, they admit that their measure is limited to capture the full set of superintendents' interaction in the network of other key environmental players (Meier and O'Toole, 2005). For measuring networking activities, scholars have not yet developed a consensus on the most appropriate measure of networking (Robinson and Gaddis, 2012). In order to correctly measure networking behaviors, Robinson and Gaddis (2012) argue that a temporal dimension (frequency in time) and an 
intensity dimension (interaction in depth) have to be considered. However, they contend that current approaches to the measurement of networking fail to capture either of these dimensions.

To measure networking, this study counts the number of key environmental actors with whom a superintendent holds regularly scheduled meetings (police, fire department, and first responders; government relief and welfare organizations; nonprofit and relief organizations; local/community/religious organizations; other school districts; business organizations). According to Robinson and Gaddis (2012), regular meetings satisfy the temporal dimension and represent intensive networking between participants because participants who could have lots of obligations should show high motivation and commitment in order to activate and maintain regular meetings.

If networking buffers the negative impact of emergency shocks on organizational outcomes, networking may play a moderating role in the negative relationship between the number of school closing days and the district's outcome (student's TAKS score performance). To capture the moderating role, this model will use an interaction term by multiplying the number of regular meeting partners with school closing days.

\section{Control variables}

Along with school closing as an environmental shock, this study controls for some other environmental resources and constraints that may influence students' TAKS performance. They include the following variables:

\footnotetext{
- $\quad$ Students' race

- $\quad$ Students' economic status

- $\quad$ Class size

- $\quad$ Teacher's salary
} 
- $\quad$ Instructional expenditures per pupil

- $\quad$ Teacher experience

- $\quad$ Hiring more teachers after the hurricane

- $\quad$ Purchasing textbooks for displaced students

- $\quad$ Lagged TAKS pass rates (TAKS pass rates in 2005)

According to Meier and O'Toole (2001), non-white students (including black students and Latino students) as well as low-income students ${ }^{5}$ tend to find less educational resources in their homes. Thus, school districts find more difficulty in educating them than others. As a result, districts with a higher percentage of these students deal with greater task difficulty (environmental constraints). While environmental constraints may negatively influence students' performance, the literature on education finds that resources are likely to affect higher student performance (Evans, Murray and Schwab 1997; Wenglinsky 1997 both cited in Meier and O’Toole, 2001). As financial resources, instructional expenditure per pupil is controlled. Qualified teachers play important roles to promote student performance. As a proxy of qualified teachers, teacher salaries and teaching experience are controlled. For providing better education, a small class size could be a resource (or large class size could be a constraint), thus, studentteacher ratio is controlled.

Emergency response also influences routine organizational performance after the emergency. Once the organization is affected by the emergency, good emergency responses may help the organization in enhancing their routine performance. Thus, this study controls for how superintendents responded to Hurricane Rita by accounting for whether or not superintendents hired more teachers and whether or not they purchased textbooks for displaced students.

\footnotetext{
${ }^{5}$ Those who are eligible for free meal in schools.
} 
Lastly, the lagged TAKS pass rate is controlled as the O'Toole-Meier model suggests.

\section{METHOD}

Using the O'Toole-Meier model, this study employs two different statistical methodologies. The first statistical methodology is to employ an ordinary least squares regression by partially replicating Meier, O'Toole, and Hicklin's (2010) model that investigated how managerial capacity (the percentage of central office administration) moderated the negative impacts of environmental shocks (days closed due to the hurricane) on organizational performance (students' educational performance). Since their study uses the same dataset that this study utilizes, it is reasonable to partially replicate their study.

The second model questions if estimators from Meier, O'Toole, and Hicklin's (2010) model are unbiased. One of the assumptions for an ordinary least squares model is that all explanatory variables are exogenous; otherwise, the estimators are biased and inconsistent (Wooldridge, 2009). This study suspects that there is an endogenous variable: lagged performance. Generally, using a lagged dependent variable as an independent variable violates the basic assumption of the ordinary least squares regression in that an explanatory variable cannot be correlated with the error term (Kelly, 2002). In fact, the endogeneity check finds that lagged TAKS pass rates are endogenous. To account for the endogeneity problem, the second statistical methodology employs the two-stage least squares regression using six student characteristics and district resources (percentage black, Latino, and low-income students; teacher's salaries, class size, and instructional funding) as instrumental variables for the lagged TAKS pass rates (Wooldridge, 2009). ${ }^{6}$

\footnotetext{
${ }^{6}$ Meier and O'Toole (2002) used these six variables as instrumental variables to account for endogeneity for lagged performance. The current study finds that these six instrumental variables explain the linear regression of lagged TAKS pass rates by 50 percent (R-squared: .502).
} 


\section{FINDINGS: THE OLS MODEL}

The result for the OLS model is shown in Table 1. From the result, it was found that the partial effects of days of school closure on TAKS pass rates depend on the number of regular meeting partners. When superintendents had no regular meeting partners, one more day of school closure after the sixth day due to Hurricane Rita in 2005 reduced the TAKS pass rate by .308 percent in 2006. However, the negative impacts of school closure decreased as the number of regular meeting partners increased and the size of impacts of school closure changed from negative to positive as superintendents had more than 3 regular meeting partners. Although regular meetings did not show a direct impact on the TAKS pass rate, the statistical insignificance of regular meetings in this model makes sense because this study does not expect managers' regular meetings to manage the emergency to directly influence students' test performance. However, managers' interaction with external actors to manage the emergency reduced the negative impacts of Hurricane Rita on students' performance.

Among control variables, students' racial background and class size are found to influence test performance. The findings show that districts with higher percentages of white students smaller class sizes are associated with better educational performance. The unexpected finding is the negative impacts of instructional expenditure per pupil. In general, a positive relationship between spending on instruction and students' achievement is expected (Hedges, Laine, and Greenwald, 1994), but some researchers question this relationship. For instance, Hanushek (1997) reviewed 167 studies that explored effects of key resources on student performance, and he found that only 27 percent of previous studies reported positive, statistically significant relationship between expenditure per pupil and student performance. According to his 
review, 7 percent of studies even found that expenditure per pupil harmed student achievement. Based on the review of previous empirical research, Hanushek $(1996,56)$ concluded that "no strong or systematic relationship exists between spending and student performance.” This study does not aim to explore a relationship between instructional expenditure per pupil and students' test performance. However, based on education literature, the negative finding between spending on instruction per pupil and students' test performance in this analysis may be plausible. Future research may want to investigate this controversial relationship. Lastly, as expected, lagged TAKS pass rates are found to be statistically significant.

\section{FINDINGS: THE TWO-STAGE LEAST SQUARES MODEL}

Table 2 presents results of the two-stage least squares analysis with two dummy variables: days of school closure between 1 and 5 days, and for more than 5 days. No school closure is a base line in the analysis. The results found that performance of school districts were not different between school districts with no class cancelation and school districts with class cancelation between 1 and 5 days. However, school districts with more than 5 days of school closure due to Hurricane Rita had 4.397 percent lower in TAKS pass rates than school closure with no class cancelation. This finding indicates that $6^{\text {th }}$ day is an appropriate cutoff, and TEA's make-up policy turned out to be erroneous.

Findings also show that the interaction term between the number of regular meeting partners and days of school closure for more than 5 days is positive and statistically significant. The following equation is the partial effect of days of school closure for more than 5 days on 2006 TAKS pass rates:

$\frac{\partial(\text { TAKS Pass Rates in 2006) }}{\partial(\text { Days of School Closure for } 6 \text { Days or More })}=-4.397+2.121 \times(\#$ of Regular Meeting Partners $)$ 
Equation (1) implies that districts without any regular meetings in preparation for the emergency experienced a decrease of TAKS pass rates by 4.4 percent as they closed schools for more than 5 days due to Hurricane Rita in 2005. Although districts with school closure for more than 5 days had negative partial effects on TAKS pass rates, its negative effects decreased as superintendents held regular meetings. Finally, the negative partial effects turned positive as superintendents held regular meeting with more than 2 external organizations in preparation for the emergency. This finding supports the hypothesis that collaborative networking in preparation for the emergency moderates the negative impact of school closure on academic performance.

In addition to networking's moderating role, it is found that organizational performance is autoregressive; after controlling for instrumental variables, higher lagged TAKS pass rates positively influenced the current districts' TAKS pass rate. Unlike the expectation, students' characteristics did not explain the variation of TAKS pass rates in 2006 except the percentage of economically disadvantaged students. In fact, the percentage of economically disadvantaged students is found to positively influence the current TAKS pass rate. This finding is unexpected. Generally, districts find higher task difficulties when they have a higher percentage of socially and economically disadvantaged students. As a result, the percentage of low-income students who are eligible for free or reduced-price school lunch is negatively correlated with TAKS pass rates (Hicklin, O'Toole and Meier, 2008). However, the model found the positive impacts of low-income students, and it is not definite at this point what factor(s) causes such a positive association.

\section{CONCLUSION AND DISCUSSION}

Organizational performance is determined by various factors, and environmental shocks are one of the significant determinants. Environmental shocks are negligible when organizations operate 
under stable environments. In such case, managers may give more attention to internal management. However, it is a different story when organizations face massive environmental shocks such as a natural disaster - a random event that can have a huge negative impact. In most cases, organizations are not free from their environments, and this study explored the environment-performance link with special attention to the moderating role of management, collaborative networking to be specific. Findings showed that environmental shocks such as Hurricane Rita does negatively influence organizational performance. TEA set a class make-up policy for those school districts that had canceled classes for 10 days or more due to Hurricane Rita. However, results showed that school districts canceled classes for 6 days or more had significant lower TAKS pass rates than those that did not cancel classes. It implies that TEA's make-up policy was not an appropriate decision. In addition to the negative link between Hurricane Rita and districts' performance, the results also found that collaborative networking moderated the negative link between them. The finding that school districts prepared for an emergency in advance by networking with emergency-relevant external actors minimized Hurricane Rita's negative impacts on their performance suggests that management can protect core missions of an organization from uncertain environmental shocks.

Although management plays a significant role in the environment-performance link, studies of public management in an emergency context are yet to be intellectually and practically mature (Farazmand 2007). Unlike some government programs such as Medicare or Medicaid, the beneficiaries of emergency management are not clear in advance. In other words, emergency management may be directed at many and unspecified persons who may or may not suffer from unexpected potential emergencies. The public as well as administrators cannot evaluate the actual performance of emergency management unless they actually experience emergencies. In 
this sense, management in preparation for unexpected emergencies may be economically and stochastically inefficient. Although emergency preparedness is inefficient in a certain sense, public management should not take a narrow economizing approach because government is responsible for protecting its citizens against emergencies. Accordingly, more research on public management in an emergency context needs to be more actively conducted.

In this regard, this study is expected to contribute to the knowledge of public management, especially in an emergency management context. However, this study has some limitation in terms of variable measures. This study measured networking as numbers of regular meeting partners. It captured a temporal dimension and an intensity dimension of networking as previous literature suggested, but the quality of regular meetings is not controlled. One may argue that regularly meeting with one good quality external organization may be better than regular meetings with multiple low quality external organizations. However, the number of regular meeting partners represents one dimension of a superintendent's active networking, and at least this study found that managers' active networking can moderate the negative impacts of environmental shock on organizational performance. Of course, future research with a more refined measure of networking needs to follow.

In summary, massive environmental shocks are influencing organizational performance. However, management can moderate the negative shocks by networking with external actors. This study confirms that management matters to organizational performance. 
TABLE 1. Moderating Effects of Collaboration on District's Performance

\section{Using the OLS Regression}

\begin{tabular}{ll}
\hline Dependent Variable $=$ TAKS Pass Rate & Slope \\
Independent Variables & $-0.308^{* * *}$ \\
\hline Days Closed (=0 if less than 6 days) & $(0.100)$ \\
Collaborative Networking (number of regular meeting partners) & -0.400 \\
Collaborative Networking x Days Closed & $(0.428)$ \\
& $0.082^{*}$ \\
\% White Students & $(0.046)$ \\
Economically Disadvantaged Students & $0.068^{* *}$ \\
Class Size & $(0.032)$ \\
Teacher's Salary (in hundred) & 0.053 \\
Instructional Expenditures per Pupil (in thousand) & $(0.050)$ \\
Teacher's Experience & $-0.994^{* *}$ \\
More Teachers Hired & $(0.483)$ \\
Purchased Textbooks & 0.037 \\
TAKS Pass Rate in 2005 & $(0.024)$ \\
Constant & $-2.569^{* *}$ \\
\hline Observations & $(1.156)$ \\
\hline Stsquared & 0.110 \\
& $(0.286)$ \\
& 1.564 \\
& $(1.700)$ \\
& -0.253 \\
& $(1.227)$ \\
& $0.805^{* * *}$ \\
& $(0.071)$ \\
& $21.110^{*}$ \\
& $(12.619)$ \\
\hline & 74 \\
& 0.885 \\
\hline
\end{tabular}

Standard errors in parentheses; * $\mathrm{p}<0.1, * * \mathrm{p}<0.05, * * * \mathrm{p}<0.01$ 
TABLE 2. Moderating Effects of Collaboration on District's Performance Using the 2Stage Least Square Regression

Dependent Variables: TAKS Pass Rates in 2006

\begin{tabular}{|c|c|}
\hline Independent Variables & Slope \\
\hline \multirow[t]{2}{*}{ Days of School Closure (1-5 days) } & 1.626 \\
\hline & $(1.766)$ \\
\hline \multirow[t]{2}{*}{ Days of School Closure (6 days or more) } & $-4.397 * *$ \\
\hline & $(1.750)$ \\
\hline \multirow[t]{2}{*}{ Collaborative Networking (number of regular meeting partners) } & -0.562 \\
\hline & $(0.494)$ \\
\hline \multirow[t]{2}{*}{ Collaborative Networking x Days of School Closure (6 days or more) } & $2.121 * * *$ \\
\hline & $(0.812)$ \\
\hline \multirow[t]{2}{*}{$\%$ White Students (05-06) (X10) } & 0.289 \\
\hline & $(0.382)$ \\
\hline \multirow[t]{2}{*}{ Economically Disadvantaged Students } & $0.170 * *$ \\
\hline & $(0.077)$ \\
\hline \multirow[t]{2}{*}{ Class Size $(05-06)$} & -0.834 \\
\hline & $(0.519)$ \\
\hline \multirow[t]{2}{*}{ Teacher's Salary (05-06) } & 0.019 \\
\hline & $(0.027)$ \\
\hline \multirow[t]{2}{*}{ Instructional Expenditure per Pupil (05-06, in thousand) } & -0.145 \\
\hline & $(1.542)$ \\
\hline \multirow[t]{2}{*}{ Teacher's Experience (05-06) } & -0.264 \\
\hline & $(0.373)$ \\
\hline \multirow[t]{2}{*}{ More Teachers Hired } & -0.529 \\
\hline & $(2.099)$ \\
\hline \multirow[t]{2}{*}{ Textbook Purchased for Displaced Students } & 0.613 \\
\hline & $(1.401)$ \\
\hline \multirow[t]{2}{*}{ TAKS Pass Rate in 2005} & $1.200 * * *$ \\
\hline & $(0.199)$ \\
\hline \multirow[t]{2}{*}{ Constant } & -8.451 \\
\hline & $(19.055)$ \\
\hline
\end{tabular}

74

Observations

0.844

R-squared

Instrumental Variables: \% whit students, \% economically disadvantaged students, class size, teacher's salary, instructional expenditure per pupil, teacher's experience; all in 2004-05 data

Standard errors in parentheses; $* * * \mathrm{p}<0.01, * * \mathrm{p}<0.05, * \mathrm{p}<0.1$ 
FIGURE 1. Track of Hurricane Rita and Its Wind Forces

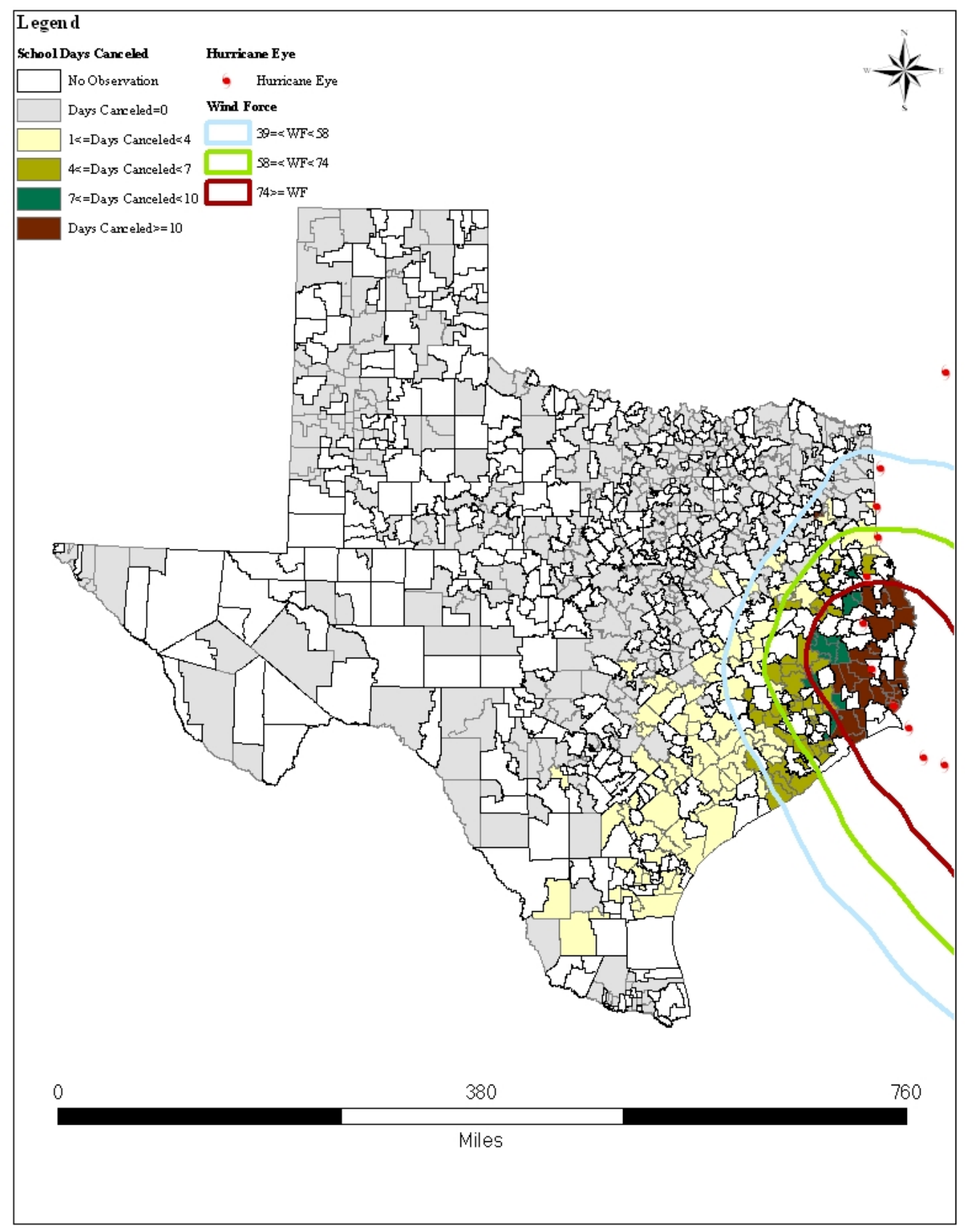




\section{REFERENCES}

Agranoff, R., \& McGuire, M. (2003). Collaborative Public Management: New Strategies for Local Governments.

Andrews, R. (2010). Organizational Structure and Public Service Performance. In R. Walker, G. Boyne \& G. Brewer (Eds.), Public Management and Performance: Research Directions. New York: Cambridge University Press.

Andrews, R., Boyne, G. A., Law, J., \& Walker, R. M. (2009). Centralization, Organizational Strategy, and Public Service Performance. Journal of Public Administration Research and Theory, 19(1), 57-80.

Behn, R. (1994). Leadership Counts: Lessons for Public Managers from the Massachusetts Welfare, Training, and Employment Program. Boston: Harvard University Press.

Berry, F. S., Brower, R. S., Choi, S. O., Goa, W. X., Jang, H., Kwon, M., et al. (2004). Three Traditions of Network Research: What the Public Management Research Agenda Can Learn from Other Research Communities. Public Administration Review, 64(5), 539-552.

Boyne, G., \& Meier, K. J. (2009). Environmental Turbulence, Organizational Stability, and Public Service Performance. Administration \& Society, 40(8), 299-824.

Bozeman, B. (2000). Bureaucracy and Red Tape. Upper Saddle River, NJ: Prentice Hall.

Brewer, G. A., \& Walker, R. M. (2010). The Impact of Red Tape on Governmental Performance: An Empirical Analysis. Journal of Public Administration Research and Theory, 20(1), 233-257.

Child, J., \& Rodrigues, S. (Writer). (2003). Corporate Governance and New Organizational Forms: Issues of Double and Multiple Agency [Article], Journal of Management \& Governance: Springer Science \& Business Media B.V.

Comfort, L. (1999). Shared Risk: Complex systems in seismic response. New York: Prgamon Press.

Erickson, P. A. (1999). Emergency Response Planning for Corporate and Municipal Managers. San Diego: Academic Press.

Evans, W. N., Murray, S. E., \& Schwab, R. M. (1997). Schoolhouses, courthouses, and statehouses after Serrano. Journal of Policy Analysis and Management, 16(1), 10-31.

Farazmand, A. (2007). Learning from the Katrina Crisis: A Global and International Perspective with Implications for Future Crisis Management. Public Administration Review, 67, 149-159.

Fleishman, R. (2009). To Participate or Not to Participate? Incentives and Obstacles for Collaboration. In R. O’Leary \& L. B. Bingham (Eds.), The Collaborative Public Manager: New Ideas for the Twenty-first Century (pp. 31-52). Washington D.C.: Georgetown University Press.

Gulick, L. (1937). Notes on the Theory of Organization. In L. Gulick \& L. Urwick (Eds.), Papers on the Science of Administration. New York: Columbia University Press.

Hanushek, E. A. (1996). School Resources and Student Performance. In G. Burtless (Ed.), Does Money Matter? The Effects of School Resources and Student Achievement and Adult Success. Washington DC: The Brookings Institution.

Hanushek, E. A. (1997). Assessing the Effects of School Resources on Student Performance: An Update. Educational Evaluation and Policy Analysis, 19(2), 141-164.

Hedges, L. V., Laine, R. D., \& Greenwald, R. (1994). An Exchange: Part I: Does Money Matter? A MetaAnalysis of Studies of the Effects of Differential School Inputs on Student Outcomes. Educational Researcher, 23(3), 5-14.

Hicklin, A., O'Toole, L. J., \& Meier, K. J. (2008). Serpents in the Sand: Managerial Networking and Nonlinear Influences on Organizational Performance. Journal of Public Administration Research and Theory, 18(2), 253-273.

Kapucu, N. (2008). Collaborative emergency management: better community organising, better public preparedness and response. Disasters, 32(2), 239-262.

Kapucu, N., Arslan, T., \& Demiroz, F. (2010). Collaborative emergency management and national emergency management network. Disaster Prevention and Management, 19(4), 452-468.

Kapucu, N., Augustin, M.-E., \& Garayev, V. (2009). Interstate Partnerships in Emergency Management: Emergency Management Assistance Compact in Response to Catastrophic Disasters. Public Administration Review, 69(2), 297-313.

Kaufman, H. (1981). The Administrative Behavior of Federal Bureau Chiefs. Washington DC: The Brookings Institution.

Kelly, N. J. (2002). The Nature and Degree of Bias in Lagged Dependent Variable Models. Paper presented at the Annual Meeting of the Southern Political Science Association. 
Keng, L., McClarty, K. L., \& Davis, L. L. (2008). Item-Level Comparative Analysis of Online and Paper Administrations of the Texas Assessment of Knowledge and Skills. Applied Measurement in Education, 21(3), 207-226.

Maslow, A. (1943). A Theory of Human Motivation. Psychological Review, 50(4), 370-396.

Mayo, E. (1949). Hawthorne and rhe Wesrern Electrical Company: The Social Problems of an Industrial Civilization. London: Routledge.

McGregor, D. (1960). The Human Side Of Enterprise. New York: McGraw-Hill.

McGuire, M., \& Silvia, C. (2010). The Effect of Problem Severity, Managerial and Organizational Capacity, and Agency Structure on Intergovernmental Collaboration: Evidence from Local Emergency Management. [Article]. Public Administration Review, 70(2), 279-288.

Meier, K. J., \& Bohte, J. (2000). Ode to Luther Gulick. Administration \& Society, 32(2), 115-137.

Meier, K. J., \& O'Toole, L. J. (2001). Managerial Strategies and Behavior in Networks: A Model with evidence from U.S. Public Education. Journal of Public Administration Research and Theory, 11(3), 271-295.

Meier, K. J., \& O'Toole, L. J. (2002). Public Managemetn and Organizational Performance: The Impact of Manaterial Quality. journal of Policy Analysis and Management, 21(3), 629-643.

Meier, K. J., \& O'Toole, L. J. (2003). Public Management and Educational Performance: The Impact of Managerial Networking. Public Administration Review, 63(6), 689-699.

Meier, K. J., \& O'Toole, L. J. (2009a). The Dog That Didn't Bark: How Public Managers Handle Environmental Shocks. Public Administration, 87(3), 485-502.

Meier, K. J., \& O'Toole, L. J. (2009b). The Proverbs of New Public Management: Lessons from and Evidence-based Research Agenda. The American Review of Public Administration, 39(1), 4-22.

Meier, K. J., O'Toole, L. J., \& Hicklin, A. (2010). I've Seen Fire and I've Seen Rain: Public Management and Performance After a Natural Disaster. Administration \& Society, 41(8), 979-1003.

Meier, K. J., \& O'Toole, L. J. (2005). Managerial networking: Issues of measurement and research design. Administration \& Society, 37(5), 523-541.

Moynihan, D. P., \& Pandey, S. K. (2005). Testing How Management Matters in an Era of Government by Performance Management. Journal of Public Administration Research and Theory, 15(3), 421439.

Nicholson-Crotty, S., \& O'Toole, L. J. (2004). Testing a Model of Public Management and Organizational Performance: The Case of Law-Enforcement Agenceis. Journal of Public Administration Research and Theory, 14(1), 1-19.

O'Toole, L. J., and Kenneth J. Meier. (2001). Managerial Strategies and Behaviors in Networks: A Model with Evidence from U.S. Public Education. Journal of Public Administration Research and Theory, 11(3).

O'Toole, L. J., \& Meier, K. J. (1999). Modeling the Impact of Public Management: Implications of Structural Context. Journal of Policy Analysis and Management, 9(4), 505-526.

O'Toole, L. J., \& Meier, K. J. (2003). Plus ça Change: Public Management, Personnel Stability, and Organizational Performance. Journal of Public Administration Research and Theory, 13(1), 4364.

O'Toole, L. J., \& Meier, K. J. (2011). Public Management: Organizations, Governance, and Performance. Cambridge: Cambrdige University Press.

Pandey, S., Coursey, D., \& Moynihan, D. (2007). Organizational Effectiveness and Bureaucratic Red Tape: A Multimethod Study. Public Performance and Management Review, 30(3), 398-425.

Park, S. M., \& Rainey, H. G. (2008). Leadership and Public Service Motivation in U.S. Federal Agencies. International Public Management Journal, 11(1).

Provan, K. G., \& Milward, H. B. (1995). A Preliminary Theory of Interorganizational Network Effectiveness: A Comparative Study of Four Community Mental Health Systems. Administrative Science Quarterly, 40(1), 1-33.

Rainey, H. G. (2009). Understanding and Managing Public Organizations (4 ed.). San Francisco: JosseyBass.

Rethemeyer, R. K., \& Hatmaker, D. M. (2008). Network Management Reconsidered: An Inquiry into Management of Network Structures in Public Sector Service Provision. Journal of Public Administration Research and Theory, 18(4), 617-646.

Rittel, H. W. J., \& Webber, M. M. (1973). Dilemmas in a general theory of planning. Policy Sciences, 4(2), 155-169. 
Robinson, S. E., \& Gaddis, B. S. (2012). Seeing Past Parallel Play: Survey Measures of Collaboration in Disaster Situations. Policy Studies Journal, 40(2), 256-273.

Taylor, F. (1911). The Principles of Scientific Management. New York: Harper.

Texas_Education_Agency. (2005). Schools respond to hurricanes, evacuees. from Texas Education Agency: http://ritter.tea.state.tx.us/press/tet/web october 2005.pdf

Thompson, J. D. (1967). Organizations in action. New York: McGraw-Hill

Trottier, T., Van Wart, M., \& XiaHu, W. (2008). Examining the Nature and Significance of Leadership in Government Organizations. Public Administration Review, 68(2), 319-333.

Waugh, W. L., \& Streib, G. (2006). Collaboration and Leadership for Effective Emergency Management. . Public Administration Review, 66(s1), 131-140.

Wenglinsky, H. (1997). How Educational Expenditures Improve Student Performance and How They Don't. Princeton, NJ: Educational Testing Service.

Wooldridge, J. M. (2009). Introductory econometrics : a modern approach (4th ed.). Mason, OH: South Western, Cengage Learning.

Wright, B. E. (2004). The role of work context in work motivation: a public sector application of goal and social cognitive theories. [Article]. Journal of Public Administration Research \& Theory, 14(1), 59. 